\title{
Kader hidup sehat dalam upaya promotif penyakit denegeratif
}

\author{
Emy Huriyati, ${ }^{1,}$ Prima Dhewi Ratrikaningtyas, ${ }^{2}$ Siti Rahmah Projosasmito, ${ }^{3}$ Arta Farmawati ${ }^{4}$ \\ ${ }^{1}$ Departemen Gizi Kesehatan, Fakultas Kedokteran, Kesehatan Masyarakat, dan Keperawatan, \\ Universitas Gadjah Mada, Yogyakarta, Indonesia \\ ${ }^{2}$ Departemen Biostatistik dan Populasi Kesehatan, Fakultas Kedokteran Kesehatan Masyarakat, dan \\ Keperawatan, Universitas Gadjah Mada, Yogyakarta, Indonesia \\ ${ }^{3}$ Departemen Pendidikan Kedokteran, Fakultas Kedokteran, Kesehatan Masyarakat, dan Keperawatan, \\ Universitas Gadjah Mada, Yogyakarta, Indonesia \\ ${ }^{4}$ Departemen Biokimia, Fakultas Kedokteran, Kesehatan Masyarakat, dan Keperawatan, Universitas \\ Gadjah Mada, Yogyakarta, Indonesia
}

\section{Submitted: 24 November 2018 Revised: 10 Januari 2019 Accepted: 12 Januari 2019}

\begin{abstract}
ABSTRAK Penyakit degeneratif terjadi karena interaksi antara genetik dan gaya hidup. Penyakit degeneratif prevalensinya semakin lama semakin meningkat. Prevalensi penyakit tidak menular di Kabupaten Sleman lebih tinggi dari rata-rata provinsi dan menduduki posisi kedua se-Daerah Istimewa Yogyakarta (DIY). Prevalensi penderita diabetes melitus mencapai 3,1\%, sedangkan obesitas sentral mencapai $29,8 \%$. Kader kesehatan sudah menjalankan kegiatan pos pelayanan terpadu (posyandu) secara rutin tetapi peran dalam pencegahan terhadap risiko terjadinya penyakit degeneratif di Dusun Denokan, Maguwoharjo, Depok, Sleman belum berjalan dengan baik. Upaya pelayanan promotif di posyandu perlu didukung oleh kader yang berkualitas. Metode penelitian ini adalah kuasi eksperimental dengan desain one group pre-test and post-test pada kader kesehatan yang diberi penyuluhan, tutorial, serta diskusi 2 arah antara pemateri dan kader terhadap kader yang belum memahami materi. Materi post-test adalah pengetahuan kader sebelum diadakan penyuluhan dan diskusi. Kader dipilih secara konsekutif dari seluruh kader yang ada di Dusun Denokan, Maguwoharjo, Depok, Sleman, DIY. Hasil pengukuran dianalisis menggunakan analisis kuantitif dan diuji dengan paired $t$ test. Hasil penyampaian materi tidak berdampak signifikan secara statistik terhadap peningkatan pengetahuan tentang penyakit degeneratif $p=0,225$ dengan nilai pre-test $4,3 \pm 1,6$ dan post-test $4,8 \pm 1,4$. Walaupun secara statistik tidak bermakna, namun terdapat kenaikan nilai antara pre-test dan post-test sebesar 0,4 . Kesimpulan yang didapat yaitu terdapat peningkatan rata-rata pengetahuan sebelum dan sesudah penyuluhan.
\end{abstract}

KATA KUNCI kader hidup sehat; penyakit degeneratif; upaya promotif

ABSTRACT Degenerative diseases occur because of interactions between genetics and lifestyle. The prevalence of non-communicable diseases in Sleman Regency is higher than the provincial average and occupies the second position in Daerah Istimewa Yogyakarta (DIY) or Special Region of Yogyakarta. The prevalence of diabetes mellitus 3.1\%, however, central obesity reached $29.8 \%$. Health cadres have routinely carried out posyandu activities but have a role in preventing the risk of degenerative diseases which have not gone well. The research methods is quasi-experimental with one group pre-test and post-test design on health cadres who were given counseling, tutorial, and discussions. The post test material was the cadre's knowledge before counseling and discussion were held. The measurement results are analyzed using quantitatif and pair $t$ test analysis. The results of material delivery did not have a significant effect on the increase in knowledge of degenerative diseases $p=0.225$ known from the pre-test $4.3 \pm 1.6$ and

\footnotetext{
*Corresponding author: Emy Huriyati

Departemen Gizi Kesehatan, Fakultas Kedokteran, Kesehatan Masyarakat, dan Keperawatan, Universitas Gadjah Mada, Jl. Farmako, Sekip Utara, Yogyakarta 55281, Indonesia

E-mail: emyhuriyati@ugm.ac.id
} 
post-test $4.8 \pm 1.4$ with an increase in the mean of 0.4. Although statistically does not show significance, there is an increase in the value between pre and post test. There is an increase in the average knowledge before and after counseling.

KEYWORDS cadre of healthy life; degenerative disease; promotive efforts

\section{Pendahuluan}

Penyakit tidak menular tentunya menjadi sorotan bagi dunia kesehatan. Penyakit tidak menular tidak terjadi begitu saja. Selain disebabkan oleh faktor genetik juga dapat terjadi karena gaya hidup yang tidak sehat, seperti halnya kurang aktivitas fisik, pola makan yang tidak sehat, serta kurangnya pengetahuan akan gizi dan kesehatan. Penyakit tidak menular yaitu diabetes melitus, hipertensi, stroke, jantung koroner, dan lain-lain merupakan silent killer yang selama dekade terakhir ini prevalensinya mengalami peningkatan.

Kelompok yang berisiko mengalami penyakit tidak menular di atas antara lain adalah orang dengan obesitas. Perubahan gaya hidup masa kini bersamaan dengan perubahan pola makan yang cenderung mengkonsumsi makanan tinggi energi (protein, karbohidrat, lemak) dan rendah serat. Pola makan yang demikian dapat meningkatkan kejadian overweight dan obesitas. ${ }^{1}$ Prevalensi anak di bawah usia lima tahun (balita) gemuk di Kabupaten Sleman berada di atas rata-rata provinsi, yaitu $12,7 \%$. Selain itu, aktivitas fisik di Kabupaten Sleman tergolong masih kurang dibanding rata-rata provinsi $(15,5 \%) .{ }^{2}$ Hal tersebut merupakan faktor terhadap kejadian penyakit degeneratif.

Prevalensi penyakit tidak menular di Kabupaten Sleman lebih tinggi dari rata-rata provinsi dan menduduki posisi kedua se-Daerah Istimewa Yogyakarta (DIY). ${ }^{2}$ Prevalensi penderita diabetes melitus mencapai $3,1 \%$ dan obesitas sentral mencapai $29,8 \%{ }^{2}$ Prevalensi tersebut terbilang cukup tinggi di Provinsi DIY dan menduduki posisi kedua terbesar dalam kategorinya. Obesitas perlu mendapatkan perhatian khusus mengingat hubungannya dengan penyakit kardiovaskular dan kanker. $^{3}$
Upaya promotif terhadap kejadian penyakit degeneratif di Kabupaten Sleman sangat perlu untuk dilakukan. Sebelumnya telah dilakukan kegiatan Community and Family Health Care Inter-Professional Education (CFHC-IPE) di Dusun Denokan, Kelurahan Maguwoharjo, Kecamatan Depok, Kabupaten Sleman oleh mahasiswa dari tiga program studi (prodi) di Fakultas Kedokteran, Kesehatan Masyarakat, dan Keperawatan (FK-KMK), Universitas Gadjah Mada (UGM). Dari hasil kegiatan tersebut diketahui bahwa dua masalah utama kesehatan penyakit tidak menular yang ditemukan adalah hiperkolesterolemia dan diabetes melitus.

Dua masalah kesehatan utama di Dusun Denokan tersebut merupakan penyakit tidak menular yang belum banyak diperhatikan. Dari masalah tersebut timbul ide untuk membentuk suatu kegiatan pemberdayaan kader yang sudah ada untuk diperkaya ilmu dan pemahamannya terkait dengan penyakit degeneratif (faktor risiko, dampak, serta pencegahannya) serta peran gizi di dalamnya sehingga dapat menjadi upaya preventif terhadap kejadian penyakit tidak menular.

Selama ini, peran kader kesehatan sudah berjalan untuk kegiatan pos pelayanan terpadu (posyandu) rutin, tetapi peran dalam pencegahan terjadinya penyakit degeneratif di Dusun Denokan, Maguwoharjo, Depok, Sleman belum berjalan. Oleh karena itu, pengabdian masyarakat ini bertujuan agar tercipta kader kesehatan yang dapat menyehatkan diri sendiri, keluarga, dan masyarakat di Dusun Denokan dengan melakukan deteksi serta pencegahan terhadap penyakit degeneratif.

\section{Metode}

Pengabdian masyarakat dilakukan dengan cara studi pendahuluan oleh mahasiswa CFHC untuk 
mengientifikasi masalah prioritas di Dusun Denokan, Maguwoharjo, Sleman. Selanjutnya, mahasiswa CFHC-IPE memberikan tambahan wawasan terkait upaya preventif terhadap kejadian penyakit degeneratif kepada kader yang sudah ada di Dusun Denokan. Program ini dilakukan melalui metode penyuluhan dan tutorial.

\subsection{Penyuluhan}

Penyuluhan dilakukan dengan menyebarkan informasi dan menanamkan pemahaman sehingga masyarakat mitra dapat meningkat pemahamannya tentang faktor risiko dan dampak dari penyakit degeneratif, upaya pencegahan penyakit degeneratif, serta peran gizi dalam pencegahan penyakit degeneratif. Kegiatan penyuluhan yang dilakukan dipadukan dengan unsur permainan mendidik sehingga peserta tidak merasa bosan. Selain itu, penggunaan alat peraga juga dilakukan, contohnya dengan menggunakan lembar balik, alat peraga gizi seimbang, dan lainnya. Terdapat empat sesi dalam setiap pertemuan penyuluhan ini, yaitu:

a. Pre-test. Tes sebelum dilakukan penyuluhan yang ditujukan untuk mengetahui pengetahuan awal yang telah dimiliki oleh mitra terkait materi yang akan disampaikan.

b. Penyampaian materi. Pemateri adalah orang yang telah berkompetensi dalam bidang tersebut serta memiliki kemampuan public speaking yang menarik.

c. Diskusi. Sesi diskusi digunakan untuk menciptakan komunikasi dua arah antara calon kader dengan pemateri, maupun antarcalon kader itu sendiri. Sesi diskusi kecil diterapkan setelah materi selesai disampaikan agar calon kader yang masih belum memahami materi yang disampaikan dapat bertanya lebih lanjut kepada pemateri.

d. Post-test. Tes akhir yang digunakan sebagai tolok ukur, apakah materi yang telah diberikan menambah pengetahuan awal mitra atau tidak sehingga dapat dijadikan acuan mengenai keberhasilan program.

\subsection{Tutorial}

Tutorial adalah metode pembelajaran berkelompok. Prinsip pokok tutorial adalah kemandirian mitra. Tujuan dari metode ini adalah untuk memberikan kesempatan kepada setiap peserta untuk mengembangkan kemampuan memecahkan masalah secara rasional dan mendinamiskan kegiatan kelompok dalam belajar sehingga tiap anggota merasa diri sebagai anggota kelompok dan berperan aktif dalam pemecahan masalah. Pada setiap kelompok tutorial ada satu tutor yang berfungsi sebagai fasilitator dan memicu peserta berpikir dan berdiskusi untuk pemecahan masalah. Pada metode tutorial, diskusi dapat berjalan apabila peserta telah memiliki pengetahuan dasar tentang kasus yang diberikan sehingga pada kegiatan ini tutorial diterapkan setelah penyuluhan. Tutorial bermanfaat untuk mempertajam pengetahuan dan mengembangkan materi dasar yang diberikan saat penyuluhan.

\subsection{Analisis Hasil}

Nilai pre-test dan post-test tentang pengetahuan penyakit degeneratif dianalisis dan disajikan secara deskriptif.

\section{Hasil}

Pelaksanaan kegiatan ini melibatkan peran aktif dari kader posyandu yang terdiri dari ibu-ibu organisasi Pemberdayaan dan Kesejahteraan Keluarga (PKK) Dusun Denokan. Kegiatan ini telah dilaksanakan dengan jumlah peserta sebanyak 9 orang yang merupakan kader posyandu. Kegiatan ini terdiri dari penyuluhan terkait penyakit degeneratif, di antaranya adalah diabetes melitus, hipertensi, kanker, dan pola hidup sehat. Selain itu, terdapat tutorial kasus dan praktik pengukuran status gizi. Sejauh kegiatan ini berjalan, hanya penyuluhan saja yang dapat dilakukan karena sulit mencari waktu luang peserta (ibu kader).

Penyuluhan yang dilakukan terdiri dari 4 materi, yaitu mengenai diabetes melitus, hipertensi, kanker, dan pola hidup sehat. Setiap materi membahas 
mengenai definisi, gejala, dampak, faktor risiko, pencegahan, dan tata laksana. Penyampaian materi dilakukan dengan menggunakan metode ceramah dan diskusi dua arah. Ceramah yang dilakukan menggunakan sarana Microsoft PowerPoint dan lembar balik. Kedua cara tersebut digunakan karena mudah dalam penyampaian dan dapat digunakan untuk meneruskan materi dari kader yang dilatih terhadap masyarakat setempat. Lembar balik yang digunakan tersebut dibagikan kepada kader sebagai panduan untuk menyampaikan materi terhadap masyarakat sekitar sehingga ilmu yang didapatkan dapat berguna dan bermanfaat. Selain itu, diharapkan keluhan yang muncul, hasil dari Focus Group Discussion (FGD) CFHC yaitu kolesterolemia dan diabetes melitus, dapat dicegah dan dideteksi lebih dini sehingga mendapatkan penanganan yang optimal.

Untuk mengetahui tingkat keberhasilan penyampaian materi, dilakukan pre-test dan posttest. Para kader diberikan soal pre-test yang terdiri dari 10 soal terkait materi yang diberikan untuk mengukur tingkat pengetahuan dasar yang dimiliki. Setelah diberikan materi terkait, dilakukan diskusi singkat. Di akhir kegiatan dilakukan post-test yang terdiri dari 10 soal yang sama untuk mengetahui sejauh mana materi yang disampaikan dapat diterima oleh kader.

Tabel 1. Hasil pre-test dan post-test penyuluhan kader

\begin{tabular}{ccccc}
\hline No & Kader & Pre & Post & Delta \\
\hline 1 & A & 3 & 4 & 1 \\
2 & B & 5 & 6 & 1 \\
3 & C & 4 & 6 & 2 \\
4 & D & 4 & 5 & 1 \\
5 & E & 3 & 4 & 1 \\
6 & F & 7 & 6 & -1 \\
7 & G & 5 & 4 & -1 \\
8 & H & 6 & 6 & 0 \\
9 & I & 2 & 2 & 0 \\
\hline Rata-rata & & 4,3 & 4,8 & 0,4 \\
\hline
\end{tabular}

Hasil analisis statistik dari nilai pre-test dan post-test (Tabel 1) menunjukkan bahwa penyampaian materi tidak berdampak signifikan terhadap peningkatan pengetahuan tentang penyakit degeneratif nilai rata-rata pre-test sebesar $4,3 \pm 1,6$, sedangkan nilai rata-rata post-test 4,8 \pm 1,4 , sehingga terdapat kenaikan rata-rata sebesar $0,4(p=0,225)$.

\section{Pembahasan}

Indikator keberhasilan peningkatan pengetahuan kader dalam pelaksanaan pelatihan kader diukur dari rata-rata nilai pre-test dan post-test. Sikap dan keterampilan kader dapat diketahui dari pengamatan saat dilakukan tutorial pelatihan kader. Menurut Notoadmodjo, ${ }^{7}$ pengetahuan diperoleh dari proses belajar. Dalam pelatihan kader ini, proses belajar yang dilakukan adalah penyampaian materi dan diskusi setelah pemberian materi serta tutorial. Materi yang disampaikan yaitu diabetes melitus, hipertensi, kanker, dan pola hidup sehat. Berdasarkan nilai pre-test dan post-test, diketahui bahwa penyampaian materi dalam pelatihan kader tidak berdampak signifikan terhadap peningkatan pengetahuan tentang penyakit degeneratif $(p=0,225)$. Meskipun secara statistik tidak menunjukkan signifikansi, tetapi ada kenaikan nilai rata-rata antara pre-test dan post-test sebesar 0,4 . Hasil tersebut tidak sejalan dengan penelitian Lubis ${ }^{4}$ pada kader posyandu di Kota Medan, yang menyatakan bahwa terdapat perbedaan bermakna pengetahuan dan tindakan kader sebelum dan sesudah mengikuti pelatihan tentang pemantuan pertumbuhan anak balita. Jadi pelatihan yang diberikan mempengaruhi tingkat pengetahuan dan tindakan kader dalam menilai dan memantau pertumbuhan balita. Dalam penelitian yang dilakukan Fatmah dan Yusran ${ }^{5}$ di Jakarta Barat, diketahui bahwa tidak terdapat hubungan bermakna antara peningkatan pengetahuan responden dengan usia, tingkat pendidikan terakhir, lama kerja sebagai kader, dan keikutsertaan dalam pelatihan gizi kesehatan sebelumnya.

Peningkatan nilai antara pre-test dan post-test dapat disebabkan karena adanya informasi baru 
yang diterima dalam pelatihan, informasi baru tersebut dapat mengganti informasi yang telah diperoleh sebelumnya atau menyempurnakan informasi yang telah diterima sebelumnya. ${ }^{5}$ Menurut penelitian Wardani ${ }^{6}$ di Kecamatan Sumbang, Kabupaten Banyumas, diketahui bahwa terdapat hubungan antara keaktifan dan minat kader kesehatan dengan tingkat pengetahuan kader kesehatan thalassaemia $(p<0,05)$. Penelitian Suryani ${ }^{7}$ di Bantul juga menyatakan bahwa meningkatnya pengetahuan kader dalam pelatihan dipengaruhi oleh keaktifan dan perhatian kader selama proses pelatihan.

Penelitian Lubis ${ }^{4}$ di Kota Medan menunjukkan bahwa kurikulum, pengajar, penyelenggara, sarana yang digunakan, metode, dan karakteristik peserta pelatihan, seperti umur, pekerjaan, pendidikan, dan pengalaman, merupakan komponen yang dapat memengaruhi keberhasilan pelatihan. Adanya pengaruh luar, baik dari media massa (cetak dan audiovisual) maupun sumber lain, yang tidak dikontrol dalam penelitian tersebut dapat memengaruhi pengetahuan dan keterampilan kader tentang penyakit degeneratif. ${ }^{8}$ Peningkatan retensi pengetahuan dan keterampilan seseorang dapat dipengaruhi oleh adanya informasi atau pengetahuan yang sering dan berulang-ulang. ${ }^{8}$ Kurangnya pengetahuan kader dapat disebabkan oleh terbatasnya pembinaan kader terutama dari tenaga kesehatan di pusat kesehatan masyarakat (puskesmas) atau dinas kesehatan. ${ }^{4}$

Kader kesehatan adalah orang yang dipilih oleh masyarakat untuk bekerja secara sukarela dan bertugas mengembangkan masyarakat. ${ }^{9}$ Peran kader dalam penyelengaraan posyandu yaitu sebagai promotor kesehatan, yang dapat memberikan informasi kesehatan kepada masyarakat, menggerakkan masyarakat untuk melakukan perilaku hidup bersih dan sehat, dan mengajak masyarakat untuk datang ke posyandu. ${ }^{10}$ Peran kader dalam posyandu dapat membantu masyarakat dalam mengurangi angka kejadian gizi buruk serta angka kematian ibu dan balita. ${ }^{11}$

Pelatihan yang diberikan pada kader, yaitu penyuluhan terkait penyakit degeneratif, tutorial kasus, dan praktik pengukuran status gizi, bertujuan untuk meningkatkan pengetahuan, keterampilan, dan sikap kader. Adanya pelatihan terhadap kader posyandu juga diharapkan dapat memotivasi kader sehingga dapat meningkatkan kinerja kader dalam melaksanakan kegiatan posyandu. ${ }^{11}$

Menurut Notoatmodjo, ${ }^{12}$ salah satu strategi untuk mengubah perilaku adalah dengan memberikan informasi untuk meningkatkan pengetahuan sehingga timbul kesadaran yang akan membuat seseorang berperilaku sesuai dengan pengetahuan tersebut. Salah satu cara pemberian informasi tersebut yaitu melalui pelatihan. ${ }^{5}$ Dalam teori yang dikemukan oleh Azwar, ${ }^{13}$ dikemukakan bahwa pengetahuan seseorang menjadi salah satu faktor yang dapat memengaruhi sikap dan tindakan seseorang. Hasil penelitian Sukiarto ${ }^{14}$ juga menyatakan bahwa pelatihan dengan metode belajar tertentu dapat memberikan manfaat secara langsung terhadap perubahan kemampuan kader. Dari pengetahuan dan keterampilan baru yang didapat dalam pelatihan, kader dapat meningkatkan kinerja dan kemampuan dalam pengelolaan posyandu. Hal tersebut sejalan dengan penelitian Purnomo, ${ }^{14}$ yang menunjukkan terdapat pengaruh yang signifikan dari adanya pelatihan kader terhadap kemampuan pengelolaan posyandu di Desa Sendangsari, Pengasih, Kulon Progo ( $p=$ $0,014)$. Penelitian Sulistyorini ${ }^{15}$ juga menunjukkan bahwa terdapat hubungan yang signifikan antara motivasi dan keaktifan kader dengan kinerja kader dalam kegiatan posyandu ( $p=0,000$ dan $p=0,001)$.

Upaya pengembangan kualitas sumber daya manusia sejak dini dapat dilaksanakan secara merata apabila pelayanan kesehatan seperti posyandu dapat terlaksana secara efektif, efisien, serta dapat menjangkau semua sasaran yang membutuhkan pelayanan. ${ }^{16}$ Kader berperan dalam pelaksanaan kegiatan posyandu dan menggerakkan keaktifan ibu-ibu dalam kegiatan posyandu. Peran kader sebagai pelaksana kegiatan di posyandu yaitu mengisi dan melengkapi Kartu Menuju Sehat (KMS) balita sebagai informasi tumbuh kembang balita. Kader juga berperan dalam memberikan pemahaman kepada ibu balita untuk peningkatan 
status gizi dan tumbuh kembang balita. Pemahaman yang diberikan kepada ibu balita di antaranya yaitu menjelaskan data KMS setiap balita atau keadaan anak berdasarkan data kenaikan berat badan dalam grafik KMS. Peran kader dalam menggerakkan keaktifan ibu-ibu di posyandu dapat dilakukan dengan mengadakan diskusi kelompok ibu-ibu yang lokasi rumahnya berdekatan dan kegiatan kunjungan rumah. ${ }^{11}$ Dampak baik yang dirasakan oleh masyarakat dengan adanya peningkatan kemampuan pengelolaan posyandu setelah pelatihan berhasil dilaksanakan yaitu kemudahan dalam mendapatkan informasi dan pelayanan kesehatan bagi ibu dan anak, serta dapat memantau pertumbuhan anak dan balita. ${ }^{14}$

Penelitian ini memiliki keterbatasan, secara rutin yaitu tidak menggunakan kelompok pembanding sehingga dapat memengaruhi tingkat akurasi data. Selain itu, pelatihan kader ini juga tidak mengontrol pengaruh luar yang dapat memengaruhi pengetahuan dan keterampilan kader.

\section{Kesimpulan}

Ada peningkatan rata-rata pengetahuan sebelum dan sesudah penyuluhan walaupun tidak bermakna secara statistik. Perlu diberikan edukasi yang terus menerus dan terprogram oleh kader sehingga pengetahuan kader terus meningkat dan perilaku hidup sehat di daerah tersebut dapat terwujud.

\section{Ucapan terima kasih}

Terima kasih kami ucapkan kepada masyarakat Dusun Denokan, Maguwoharjo, Sleman atas partisipasinya dalam program pengabdian kepada masyarakat ini. Program ini bisa terwujud atas pemberian dana hibah Pengabdian Masyarakat Terintegrasi, dari Fakultas Kedokteran, Kesehatan Masyarakat, dan Keperawatan, UGM tahun 2017.

\section{Konflik kepentingan}

Penulis menyatakan tidak ada konflik kepentingan dalam penelitian ini.

\section{Daftar pustaka}

1. Rahmadani L, Indriasari R. Hubungan aktivitas sedentari dengan kejadian overweight pada remaja di SMA Katolik Cendrawasih Makassar [bachelor's thesis]. Makassar: Universitas Hasanuddin; 2014.

2. Dinas Kesehatan Daerah Istimewa Yogyakarta. Media advokasi Provinsi DIY: Pembangunan kesehatan di Daerah Istimewa Yogyakarta. Yogyakarta: Dinas Kesehatan Daerah Istimewa Yogyakarta; 2013.

3. Abdelaal $M$, le Roux CW, Docherty NG. Morbidity and mortality associated with obesity. Ann Transl Med. 2017;5(7):161.

4. Lubis Z, Syahri IM. Pengetahuan dan tindakan kader posyandu dalam pemantauan pertumbuhan anak balita. KEMAS. 2015;11(1):65-73

5. Fatmah, Nasution Y. Peningkatan pengetahuan dan keterampilan kader posbindu dalam pengukuran tinggi badan prediksi lansia penyluhan gizi seimbang dan hipertensi studi di Kecamatan Grogol Petamburan, Jakarta Barat. MMI. 2012;46(1):61-8.

6. Wardani NII, Sri Rejeki DS, Masfiah S. Faktorfaktor yang berhubungan dengan tingkat pengetahuan kader kesehatan tentang thalassaemia di Kecamatan Sumbang Kabupaten Banyumas. Kesmasindo. 2014;6(3):194-206.

7. Suryani ED, Isnaeni Y. Pengaruh pelatihan kader terhadap kemampuan melakukan pengelolaan posyandu di Desa Srihardono Pundong Bantul Yogyakarta [bachelor's thesis] Yogyakarta: Sekolah Tinggi Ilmu Kesehatan 'Aisyiyah; 2013.

8. Fatmah. Pengaruh pelatihan pada peningkatan dan keterampilan teknis penyuluhan obesitas dan hipertensi Kader Posbindu Kota Depok. Makara Seri Kesehatan. 2013;17(2):49-54.

9. Triyanti M, Laksmono W, Syamsulhuda BM. Peningkatan pengetahuan dan ketrampilan kader pemantauan tumbuh kembang balita di posyandu dengan metode BBM dan Mind Mapping (MM). JPKI. 2017;12(2):265-77. 
10. Kementerian Kesehatan Republik Indonesia. Ayo ke posyandu setiap bulan. Jakarta: Kementerian Kesehatan Republik Indonesia; 2012.

11. Hardiyanti P. Peran kader terhadap peningkatan gizi balita di Desa Banyuraden Sleman Yogyakarta [bachelor's thesis]. Surakarta: Universitas Muhammadiyah Surakarta; 2017.

12. Notoatmojo S. Promosi kesehatan dan ilmu perilaku. Jakarta: Rineka Cipta; 2014.

13. Azwar S. Sikap manusia: Teori dan pengukurannya. Yogyakarta: Pustaka Pelajar; 2015.

14. Purnomo GA. Peningkatan pelatihan kader tentang posyandu terhadap kemampuan pengelolaan posyandu di Desa Sendangsari
Kecamatan Pengasih Kulon Progo [bachelor's thesis]. Yogyakarta: Sekolah Tinggi Ilmu Kesehatan 'Aisyiyah; 2014.

15. Sulistyorini L. Pengaruh pelatihan kader posyandu terhadap motivasi dan keaktifan sebagai prokes (promotor kesehatan desa) dalam pencegah penyakit dipteri pada anak balita di Desa Karangharjo Kecamatan Silo Kabupaten Jember. The Indonesian Journal of Health Science. 2015.

16. Punikasari D. Peran posyandu dalam meningkatkan kualitas kesehatan masyarakat di Dusun Karangwatu, Desa Puncungrejo, Kecamatan Muntilan, Kabupaten Magelang [bachelor's thesis]. Yogyakarta: Universitas Negeri Yogyakarta; 2010. 